\title{
Effect of Sodium Ascorbate or Alpha-Tocopherol on the Resin-Dentin Interface and Bond Strength after Endodontic Treatment and Bleaching
}

\author{
Efecto del Ascorbato de Sodio o Alfa-Tocoferol sobre la Interfaz Resina-Dentina y \\ la Fuerza de Unión Después del Tratamiento de Endodoncia y Blanqueamiento
}

\begin{abstract}
Aryvelto Miranda Silva; Keren Cristina Fagundes Jordão-Basso; Cristiane de Melo Alencar; Joissi Ferrari Zaniboni; Edson Alves de Campos \& Milton Carlos Kuga
\end{abstract}

SILVA, A. M.; JORDÃO-BASSO, K. C. F.; ALENCAR, C. M.; ZANIBONI, J. F.; ALVES DE CAMPOS, E. \& KUGA, M. C. Effect of sodium ascorbate or alpha-tocopherol on the resin-dentin interface and bond strength after endodontic treatment and bleaching. Int. J. Odontostomat., 15(3):586-594, 2021.

\begin{abstract}
The objective of this in vitro study was to assess the effects of two antioxidants (sodium ascorbate [SA] and alpha-tocopherol [AT]) on the adhesive interface and dentin bond strength immediately after bleaching with $38 \%$ hydrogen peroxide (38HP) in endodontically-treated teeth. Two stages of experimentation were carried out. Bovine incisors were allocated into four groups ( $n=10$ /group for each experiment): NB, non-bleached restored crowns; 38HP, bleached and immediately restored crowns; 38HP-SA, bleached crowns and SA use; and 38HP-AT, bleached crowns and AT use. Hybrid layer length in dentin $(\mu \mathrm{m})$ and bond strength $(\mathrm{MPa})$ were assessed with confocal microscopy laser and micro-shear bond strength ( $\mu \mathrm{SBS}$ ) test, respectively. Failure mode was determined by stereomicroscope. Data analysis was performed with analysis of variance (ANOVA) and Kruskal-Wallis, Dunn, Tukey, and Fisher-exact tests $(a=0.05)$. Higher values of hybrid layer length were observed similarly in the NB and 38HP-SA groups. The highest $\mu$ SBS mean values were observed in the NB group (18.51 \pm 1.33$)$, whereas the SBS values for $38 \mathrm{HP}-A T(1.68 \pm 0.32)$ were similar to the $38 \mathrm{HP}$ group (1.61 \pm 0.51$)$ $(p>0.05)$ and significantly lower than the 38HP-SA group $(5.78 \pm 0.71)$. Adhesive failures were predominant in the $38 \mathrm{HP}$ and 38HP-AT groups. Cohesive and mixed failures were mostly observed in the NB and 38HP-SA groups, respectively. In conclusion, AT has no immediate effect on the hybrid layer formation and $\mu$ SBS of dentin. Although SA promotes an increase in hybrid layer formation, it was not reflected in the $\mu$ SBS values.
\end{abstract}

KEY WORDS: bleaching, alpha-tocopherol, sodium ascorbate, bond strength, hybrid layer.

\section{INTRODUCTION}

Dental bleaching is one of the non-invasive procedures that meets the public demand for cosmetic dentistry (Carey, 2014). During bleaching, free radicals formed by the interaction of bleaching agent with the tooth structure, act by reducing the chromophore molecules and thus making them less pigmented (Elawsya et al., 2021). In some cases, where the color changes have not sufficiently resolved with bleaching or there is a significant loss of tooth structure, restorative procedures are necessary on the whitened structure (Cavalli et al., 2018). However, residual peroxides can adversely affect the bond strength of adhesive restorations to tooth structure (Cvitko et al., 1991).

A recent meta-analysis (Imani et al., 2020) indicated that shear bond strength to enamel is negatively affected by bleaching procedures. Hence, post bleaching, the current recommended wait time ranges from $24 \mathrm{~h}$ to 28 days, to perform definitive restorations (Cavalli et al., 2001; Unlu et al., 2008; Comlekoglu et al., 2010). However, in endodontically treated teeth, this is not always feasible. In addition to the cost and time of new clinical sessions and 
inconvenience to the patient, a long elapsed time to the restorative treatment presents with risk of coronary failure, microleakage of temporary restorations, and recurrence of discoloration of recently bleached teeth (Carvalho et al., 2018). This is a frequent problem encountered by dental surgeons in clinical practice, and the absence of a consensual protocol has hindered the basis for making clinical decisions.

Use of antioxidants immediately after dental bleaching is one promising alternative for achievement of the adhesive procedure (Garcia et al., 2012). Ascorbic acid is an effective antioxidant, and its low toxicity indicates that the biological risks of its use are minimal. However, ascorbic acid has a low pH (around 4.0) that could cause over-conditioning of the dental surface (Lai et al., 2001). Therefore, effects of sodium ascorbate (SA), which has a neutral $\mathrm{pH}$ (around 7), have been studied to reverse the negative impact of bleaching on bonding procedure of adhesive restorations (Freire et al., 2009; Garcia et al.). Alphatocopherol (AT) is considered the most effective fatsoluble antioxidant available in nature (Burton \& Ingold, 1989) and has beneficial effects on various health conditions caused by free radicals in organic systems (Cross et al., 1987). Theoretically, this antioxidant would be able to trap free radicals in the bleached surface without converting them into reactive intermediates that could compromise adhesive restorative procedures (Sasaki et al., 2009).

A recent in vitro study demonstrated the nonsignificant short-term effect of AT in reversing the impairment of bond strength in endodontically-treated tooth bleached with sodium perborate (Harrison et al., 2019). However, bleaching procedures on endodontically treated teeth can be challenging and require more effective treatment (Doumani et al., 2019). Consequently, hydrogen peroxide has been widely used in these cases (Souza-Gabriel et al., 2011). Higher concentrations of hydrogen peroxide are associated with significant reduction in enamel shear bond strength. Furthermore, the application time was pointed out as an important factor for damage to the enamel surface (Imani et al.). The effects of dental bleaching with hydrogen peroxide associated with or without the use of antioxidants in immediate adhesive restorative procedures on dentin of endodontically treated teeth have been less explored and remain unclear.

Thus, this in vitro study aimed to assess the effects of two antioxidants (SA and AT) on the performance of adhesive restorative procedures performed immediately after simulated bleaching with $38 \%$ hydrogen peroxide in endodontically-treated teeth. The hypotheses that the use of these antioxidants would reverse the negative effect of the bleaching procedure on $(\mathrm{H} 1)$ the hybrid layer formation and $(\mathrm{H} 2)$ the microshear bond strength ( $\mu \mathrm{SBS})$, were tested. Furthermore, the effects of antioxidants on the adhesive interface were qualitatively assessed.

\section{MATERIAL AND METHOD}

Experimental design and ethical aspects. This in vitro study was conducted in two stages of experimentation: effect of antioxidants on the dentinadhesive interface (Experiment 1) and on the microshear bond strength (mSBS) (Experiment 2) on the dentin of endodontically treated teeth subjected to bleaching.

According to the study protocol, four groups were composed:

1) Non-bleached + Restored - positive control (NB): The specimens were etched, adhesive system (Scothbond Multi-Purpose; 3M ESPE, St. Paul, MN, USA) was applied, and the dental crowns were restored with composite resin (Filtek Z-250; 3M, St. Paul, MN, EUA). The primer from the adhesive system was applied onto the dentin using a brush tip (KG Sorensen, São Paulo, SP, BR) and gently dried for $5 \mathrm{~s}$. After $5 \mathrm{~s}$, dentin adhesive was applied and light-cured with a lightemitting diode (LED)-laser system (LED Bluephase; IvoclarVivadent, Schan, Liechtenstein, AL) with an intensity of $1,200 \mathrm{~mW} / \mathrm{cm} 2$ for $10 \mathrm{~s}$. The pulp chamber was then restored with composite resin, with $2 \mathrm{~mm}$ thick increments and light-cured for $40 \mathrm{~s}$ at each increment.

\section{2) Bleached with $38 \%$ hydrogen peroxide + Restored without antioxidant use - negative con- trol (38HP): The buccal surface and pulp chamber were subjected to bleaching with $38 \%$ hydrogen peroxide (Opalescence Xtra Boost; Ultradent Products Inc, South Jordan, UT, USA). The bleaching gel was handled according to the manufacturer's recommendations and applied at about $\pm 2.0 \mathrm{~mm}$ thickness to the buccal surface of the dental crown and within the pulp chamber. The gel was applied for 15 min, aspirated, and applied twice under similar conditions described above. Then the dental crown was copiously rinsed with gentle water-spray for $1 \mathrm{~min}$, dried and immediately restored, similar to group NB.}


SILVA, A. M.; JORDÃO-BASSO, K. C. F.; ALENCAR, C. M.; ZANIBONI, J. F.; ALVES DE CAMPOS, E. \& KUGA, M. C. Effect of sodium ascorbate or alpha-tocopherol on the resindentin interface and bond strength after endodontic treatment and bleaching. Int. J. Odontostomat., 15(3):586-594, 2021.

3) Bleached with $38 \%$ hydrogen peroxide + Restored after $10 \%$ SA gel use (38HP-SA): After the bleaching protocol similar to 38HP group, $10 \%$ SA gel (Apothicário, Araçatuba, SP BR) was applied for 15 min on the buccal surface and 10 min within the pulp chamber. The antioxidant was removed with a gently water-spray for $15 \mathrm{~s}$, and the tooth was immediately restored similar to the $38 \mathrm{HP}$ group.

4) Bleached with $38 \%$ hydrogen peroxide + Restored after $10 \%$ AT gel use (38HP-AT): Similar procedures to 38HP-SA group were performed, but using $10 \%$ AT gel (Apothicário, Araçatuba, SP BR) as an antioxidant. After $24 \mathrm{~h}$, the dental crowns were crosssectioned from the root portion at the cemento-enamel junction and longitudinally sectioned in bucco-lingual direction using a hard tissue cutting machine (Isomet; Buehler, Lake Bluff, IL). The distal section from each dental crown was selected, and the dentin-restoration interface was flattened with \#600 followed by \#1200 wet sandpaper (Norton, Lorena, SP, BR), under running water-cooled circular polisher (Arotec, Cotia, SP, BR).

The study protocol was approved by the local Ethics Committee.

Sample size calculation. For the sample size calculation was considered the dentin tags penetration and bond strength values of a previous study (Harrison et al.). Using a significance level of 0.05 and a test power of $80 \%$, the sample size necessary was 10 specimens. Considering all variables of the 2 experiments adopted in the study, 80 bovine teeth were selected.

Specimens preparation. Forty bovine incisors with similar crown and root anatomy (radiographically confirmed) were stored in thymol solution $(0.1 \%$; $\mathrm{pH}$ 7.0) at $4^{\circ} \mathrm{C}$ until the beginning of the research. The pulp chamber access was performed with a 1014 spherical diamond drill (KG Sorensen, Cotia, SP, Brazil), and the access diameter was standardized with a \#12 steel spherical drill.

Root canals were instrumented by crown-down technique (Morgan \& Montgomery, 1984), $1 \mathrm{~mm}$ from the root apex, up to \#80 K-file, irrigated with $5 \mathrm{~mL}$ of $2.5 \%$ sodium hypochlorite at each file change. After the biomechanical preparation, the root canals were irrigated with $3 \mathrm{~mL}$ of $17 \%$ EDTA (Biodinâmica, Ibiporã, PR, Brasil) for $3 \mathrm{~min}$, and $10 \mathrm{~mL}$ of distilled water. The canals were then aspirated and dried with absorbent paper points (Dentsply-Herpo, Petrópolis, RJ, Brasil).
The root canals were obturated using gutta-percha (Dentsply Ind Com Ltda, Petrópolis, RJ, Brasil) and epoxy-based sealer (AH Plus; Dentsply De Trey, Konstanz, Germany). The gutta-percha was removed $3 \mathrm{~mm}$ below the tooth cervical line, and a cervical barrier with self-curing glass ionomer (Maxxion R A3; FGM ProdutosOdontológicos Ltda., Joinville, SC, Brasil) was placed at the cement-enamel junction.

The access cavity was restored with provisional restorative cement (IRM; Dentsply Ind Com Ltda, Petrópolis, RJ, Brasil), and the teeth were immediately immersed in artificial saliva (Faculdade de CiênciasFarmacêuticas de Ribeirão Preto-USP, Ribeirão Preto, SP, Brasil). After $24 \mathrm{~h}$, the temporary restoration was removed, and the pulp chamber was irrigated with $2.5 \mathrm{~mL}$ of $2.5 \%$ sodium hypochlorite, and $2.5 \mathrm{~mL}$ of distilled water. Thirty-seven percent phosphoric acid (Condac 37; FGM Produtos Odontológicos Ltda., Joinville, SC, Brasil) was used to etch the dentin for $15 \mathrm{~s}$ and was rinsed off with distilled water (Kuga et al., 2012).

After $24 \mathrm{~h}$ of the experimental procedures, the dental crowns were cross-sectioned from the root portion at the cemento-enamel junction and longitudinally sectioned in bucco-lingual direction using a hard tissue cutting machine (Isomet; Buehler, Lake Bluff, IL). The distal section from each dental crown was selected, and the dentin-restoration interface was flattened with \#600 followed by \#1200 wet sandpaper (Norton, Lorena, SP, BR), under running water-cooled circular polisher (Arotec, Cotia, SP, BR).

The specimens were washed with distilled water, and the surface was polished with aluminium oxide (Arotec, São Paulo, SP, BR) at $30 \mathrm{~mm}$ granulation, and felt disc at circular polisher. Then, the specimens were immersed in distilled water and stirred in an ultrasonic tank (Cristófoli, Campo Mourão, PR, USA) for 10 min.

The specimens were dried with absorbent paper, and the whole surface was etched with $37 \%$ phosphoric acid (Condac 37; FGM Produtos Odontológicos Ltda., Joinville, SC, Brasil) for $60 \mathrm{~s}$. The surfaces were rinsed with $50 \mathrm{~mL}$ of distilled water, dehydrated with air-spray, and individually fixed on a glass slide with the etched surface kept at horizontal position.

For the $\mu$ SBS test, otherforty bovine incisors were obtained and preserved similar to the previous experiment. The crowns were transversely sectioned at the cement-enamel junction and the roots were 
discarded. The crown was sectioned in the mesiodistal direction using a hard tissue cutting machine (Isomet 100, Buehler, Lake Bluff, IL) obtaining $10 \mathrm{~mm}$ length slabs. The buccal surface of the slabs was ground with a polishing machine (DP-10; Panambra, Struers, Ballerup, DI) using \#180 silicon carbide sandpapers in order to obtain the dentin exposure and make it flat.

The exposed dentin was polished with \#320 and \#6000 sandpapers for $20 \mathrm{~s}$. The slabs were then embedded into polystyrene matrix molds $(16.5 \mathrm{~mm}$ width $¥ 25.0 \mathrm{~mm}$ length), with acrylic resin (Classic Jet, São Paulo, SP, BR) leaving the dentin surface uncovered by the acrylic resin. After the acrylic resin polymerization, the slabs were randomly allocated into 4 groups $(n=10)$, similar to Experiment 1 .

After all the dentin treatment protocols, four cylinders made of composite resin specimens were prepared on the buccal surface: two at mesial and two at distal. A Tygon tube transparent matrix (Tygon tube, R-3603, Saint-Gobain Performance Plastics, Maime Lakes, FL, USA) with $0.72 \mathrm{~mm}$ internal diameter and $1.0 \mathrm{~mm}$ height was used for the composite resin filling. (Filtek Z-250; 3M, St. Paul, MN, USA).

Hybrid-layer length in dentin. Each specimen was analyzed with a laser confocal microscope (LEXT OLS4100; Olympus, Shinjuku-ku, Tokyo, JP), using specific software (Olympus Stream; Olympus, Shinjuku-ku, Tokyo, JP), at a magnification of 1024¥ (Guarda et al., 2020). The images were saved as TIFF format, and the hybrid layer formation length in dentin was measured using the Image $\mathrm{J}$ program, calibrated in micrometers $(\mathrm{mm})$. The intra dentin length from the formed hybrid layer was measured in $100 \mathrm{~mm}$, from the buccal surface of the middle-third of the dental crown. The measurement was performed for every 10 $\mu \mathrm{m}$, and a total of 10 analyses were obtained for each specimen. The arithmetic average from these measurements indicated the hybrid layer formation in each specimen.

Micro-shear bond strength ( $\mu$ SBS) test. After obtaining the specimens, they were stored in a humid environment and mSBS test was performed after 24 h. All slabs were fixed inside a metal matrix so that the composite cylinder specimens were placed perpendicularly to the load cell of $500 \mathrm{~N}$.

An orthodontic wire $(0.2 \mathrm{~mm}$ diameter) held the composite cylinder base, and all the specimens were subjected to compressive loading in an electromechanical testing machine (DL2000; EMIC, Pinhais, PR, Brazil) with a crosshead speed of $0.5 \mathrm{~mm} /$ min until the end of mSBS test (Shimada et al., 2003). The bond strength was obtained from the maximum force $(\mathrm{N})$ divided by the union area $\left(\mathrm{mm}^{2}\right)$, in $\mathrm{MPa}$. The arithmetic average was calculated for the four specimens from each slab and called an average specimen.

Failure mode analysis. After the mSBS test, failure modes were determined analyzing a failed surface of each sample with a stereomicroscope (SZ - PT; Olympus, Japan; 40X magnification). The failures were classified as: A) adhesive, if the failure occurred totally at the adhesive interface, B) cohesive, if the failure was observed exclusively in dentin or resin, or C) mixed when a combination of adhesive and cohesive failures was observed (Sasaki et al.). Furthermore, representative images of failure modes were obtained with Scanning Electron Microscopy (SEM), at 500x magnification.

Statistical Analysis. The non-normal data distribution was verified with the Shapiro-Wilk test for the hybridlayer formation data.Thus, Kruskal-Wallis and Dunn tests were applied. Confocal fluorescence images provided qualitative data regarding the adhesive interface. The bond strength data were analyzed using one-way ANOVA and Tukey test. The failure modes data were analyzed using Fisher's exact test. Level significance at $5 \%$ was adopted for all analyses. Data acquired from SEM provided qualitative data regarding the failure modes.

\section{RESULTS}

Table I presents the hybrid layer formation values $(\mu \mathrm{m})$. The 38HP-SA group presented a hybrid layer formation similar to the NB group. With the median values of hybrid layer formation significantly inferior, the 38HP and 38HP-AT groups did not differ from each other $(p>0.05)$. Confocal fluorescence images (Fig. 1) showed that the hybrid layer formation was more uniform in the NB and 38HP-SA groups.

The highest $\mu$ SBS mean values (in MPa) (Table II) were observed in the NB group $(18.51 \pm 1.33)$. In a decreasing sequence, the $38 \mathrm{HP}-\mathrm{AS}(5.78 \pm 0.71)$ group presented higher bond strength than the 38HP-AT (1.68 $\pm 0.32)$ and $38 \mathrm{HP}(1.61 \pm 0.51)$ groups, whose values were similar to each other $(p>0.05)$. 
SILVA, A. M.; JORDÃO-BASSO, K. C. F.; ALENCAR, C. M.; ZANIBONI, J. F.; ALVES DE CAMPOS, E. \& KUGA, M. C. Effect of sodium ascorbate or alpha-tocopherol on the resindentin interface and bond strength after endodontic treatment and bleaching. Int. J. Odontostomat., 15(3):586-594, 2021.

Table I. Median, maximum, and minimum values, and the first and third quartile of the intra-dentin length from the hybrid layer formation $(\mu \mathrm{m})$.

\begin{tabular}{ccccc}
\hline & NB & $38 \mathrm{HP}$ & $38 \mathrm{HP}-\mathrm{SA}$ & $38 \mathrm{HP}-\mathrm{AT}$ \\
\hline Median & $11.23^{\mathrm{a}}$ & $3.63^{\mathrm{b}}$ & $9.86^{\mathrm{a}}$ & $3.94^{\mathrm{b}}$ \\
Max-Min & $15.26-9.91$ & $4.86-0.30$ & $10.60-8.63$ & $5.13-3.22$ \\
1Q-3Q & $10.26-11.65$ & $1.55-3.98$ & $9.06-10.24$ & $3.47-4.48$ \\
\hline
\end{tabular}

a,b Different letters indicate significant statistical difference (Dunn test, $p<0.05$ ). Max: maximum value and Min: minimum value; $1 \mathrm{Q}$ : first quartile and $3 \mathrm{Q}$ : third quartile. NB - restored crowns, 38HP - bleached and immediately restored crowns, 38HPSA - bleached crowns and sodium ascorbate use, and 38HP-AT - bleached crowns and alpha-tocopherol use.
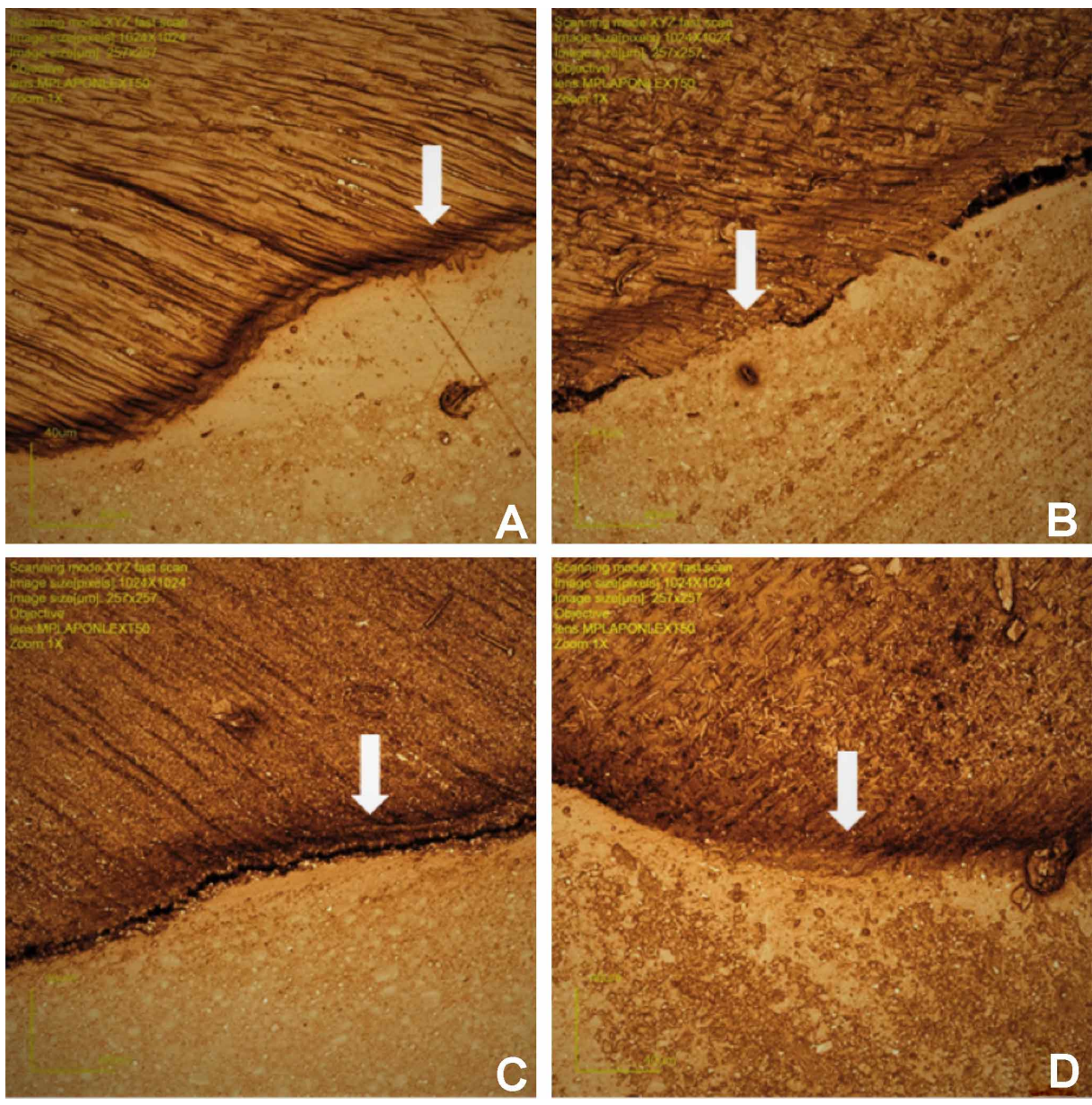

Fig. 1. Representative images showing a hybrid layer formation analysis for all groups obtained by confocal laser microscopy (1024¥ magnification). A - Restored crowns (NB), $B$ - bleached and immediately restored crowns (38HP), C - bleached crowns and sodium ascorbate use (38HP-SA), D - bleached crowns and alpha-tocopherol use (38HP-AT).

Table II. Micro-shear bond strength (in MPa) of the adhesive system to dentin

\begin{tabular}{ccccc}
\hline & NB & $38 \mathrm{HP}$ & $38 \mathrm{HP}-\mathrm{SA}$ & $38 \mathrm{HP}-\mathrm{AT}$ \\
\hline Mean & $18.51^{\mathrm{a}}$ & $1.61^{\mathrm{c}}$ & $5.78^{\mathrm{b}}$ & $1.68^{\mathrm{c}}$ \\
SD & 1.33 & 0.51 & 0.71 & 0.32 \\
\hline
\end{tabular}

$a, b$ Different letters indicate significant statistical difference (Tukey test, $p<0.05)$. SD - standard deviation, NB - restored crowns, 38HP - bleached and immediately restored crowns, 38HP-SA - bleached crowns and sodium ascorbate use, and 38HP-AT - bleached crowns and alpha-tocopherol use.
The failure modes showed in Figure 2 presented significant differences between groups $(p<0.001)$. Cohesive failures were predominant in the NB group $(67.5 \%)$. Adhesive failures (83\%) were mostly observed in the 38HP group similar to that of the 38HPAT group. Furthermore, in the 38HP-SA group, mixed failures were predominant $(72.5 \%)$. SEM representative images of each failure mode are shown in Figure 3. 


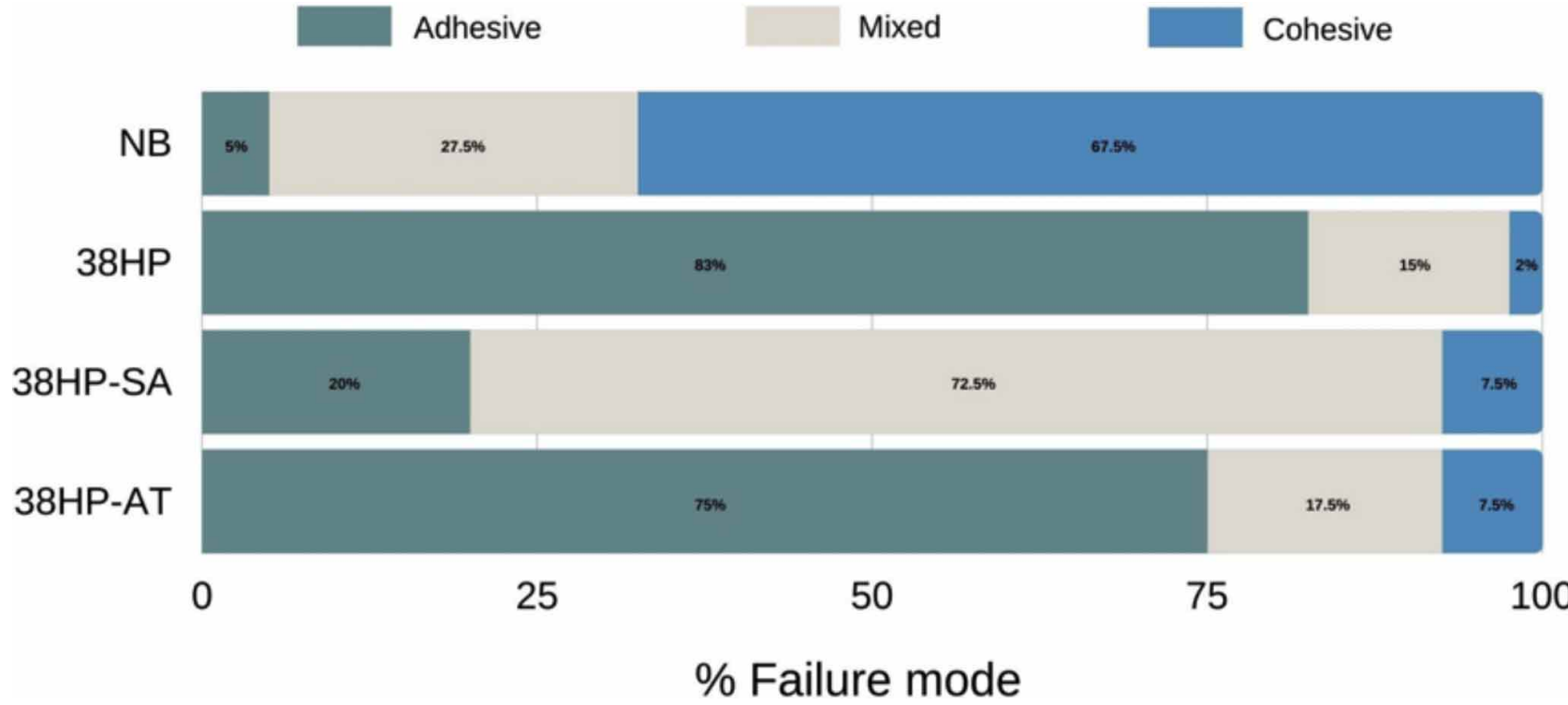

Fig. 2. Failure mode analysis for all groups after the micro-shear bond strength test. A significant statistical difference is observed (Fisher-exact test, p<0.001). NB - restored crowns, 38HP - bleached and immediately restored crowns, 38HP-SA - bleached crowns and sodium ascorbate use, and 38HP-AT - bleached crowns and alpha-tocopherol use
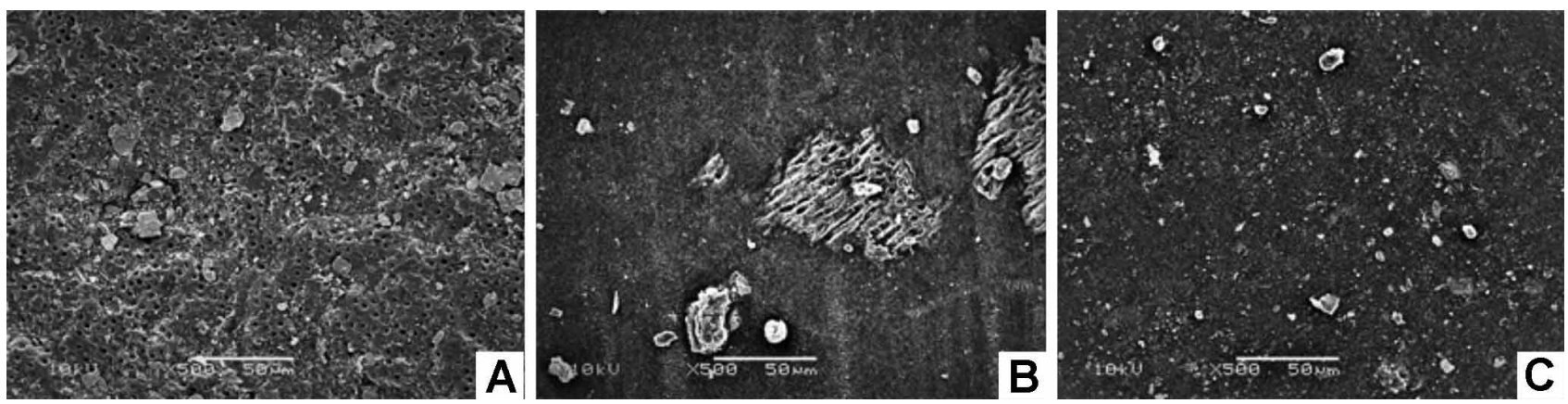

Fig. 3. Representative images showing (A) adhesive, (B) mixed, and (C) cohesive failures analyzed by scanning electronic microscopy (500¥ magnification).

\section{DISCUSSION}

The antioxidants evaluated in the present study demonstrated distinct immediate effects on the tooth structure subjected to bleaching with $38 \%$ hydrogen peroxide. SA reversed the negative effect of bleaching on the formation of a hybrid layer, presenting results similar to the non-bleached tooth structure (NB group). However, the compromise in hybrid layer formation was similar in 38HP-AT group and tooth structure without use of antioxidant post-bleaching (38HP group). Thus, $\mathrm{H} 1$ was rejected.

Dentinal tubules are permeable to bleaching agents, thus representing reservoirs of oxygen free radicals (Perdigão, 2010). These residual peroxides releasing free radicals from the bleaching agents persist in the tooth structure until they are removed by pulp microcirculation and/or diffusion from the external surface. Based on a reduced pulp microcirculation, greater external diffusion is expected. In endodontically treated teeth, a clinical condition simulated in this study, the accumulation of free radicals is very critical. Thus, increased levels of peroxide may be present at the adhesive interface, compromising resinous materials infiltration in the tubules and the formation of a uniform hybrid layer (Abraham et al., 2013). A previous study has shown that compared with the non-bleached tooth surface, bleaching causes approximately two-thirds reduction in the penetrability of resin tags on the tooth 
surface (Titley et al., 1991). This can justify the results of the present study, where the 38HP group presented a hybrid layer formation significantly inferior to the NB group.

Our findings demonstrated that the application of $10 \%$ SA immediately after bleaching, allowed the adhesive procedure to provide a hybrid layer similar to the NB group. This finding suggests that similar the occurrence in bleached enamel, SA is effective in eliminating peroxide free radicals, allowing faster polymerization of adhesive materials without any premature interruption (Briso et al., 2012; Thapa et al., 2013; Briso et al., 2014; Kavitha et al., 2016; Elawsya et al.). However, no differences in the hybrid layer formation were observed between the 38HP-AT and $38 \mathrm{HP}$ groups, demonstrating that AT did not have significant effects in reversing the effect of the bleaching procedure on the hybrid layer formation (Thapa et al.).

Sasaki et al. observed that AT was effective in neutralizing free radicals resulting from bleaching with carbamide peroxide. This may justify the divergence with the results of our study because the impairment of adhesive procedures on a recently bleached surface appears to be directly proportional to the concentration of the bleaching agent (Imani et al.). In this study, where a stronger bleaching agent was used (38 \% hydrogen peroxide), possibly a higher concentration of the AT gel would be needed to neutralize the accumulation of oxygen in the dentin that probably compromised the formation of the hybrid layer. Thus, it is strongly recommended that the effects of this antioxidant in other concentrations and/or application times be investigated.

In this study, the $\mu$ SBS test was chosen to assess the adhesive strength. This test has the advantage of greater control of the test area due to the use of tubes of known diameter (Shimada et al.). The bleaching procedure, with or without the application of antioxidants, significantly compromised the $\mu$ SBS compared with the NB group. In addition to creating a reservoir of residual oxygen, bleaching changes the mineral and protein content of dentin (Perdigão). The ineffectiveness of the antioxidants evaluated in the present study in reversing the impairment of bond strength may be associated with this fact. Thus, the $\mathrm{H} 2$ was also rejected.

Although application of SA showed an increase in bond strength compared with the bleached surface, its value was significantly lower than that of the non- bleached surface. This result is in agreement with previous studies (Sasaki et al.; Nascimento et al., 2019; Zhang et al., 2020), and the primary theory that justifies this finding is that SA can react with hydroxyl crystals or peroxiapatite resulting from bleaching (Briso et al., 2014; Rezaei et al., 2019). Thus, application of $10 \%$ SA gel for 10 min can increase the bond strength to the bleached tooth structure. However, the SBS values were lower than the non-bleached surface. As with enamel, the application of SA can cause overconditioning of the whitened surface (Muraguchi et al., 2007). This can compromise the already delicate adhesion to dentin, justifying these results.

In contrast with the previous studies (Whang \& Shin, 2015; Kavitha et al., 2016; Nari-Ratih \& Widyastuti, 2019), the findings of this study demonstrated that SA effects were significantly higher than the group using AT. However, in these studies, AT was applied as an alcohol-based solution. Therefore, a similar effect of AT cannot be attributed exclusively to the antioxidant because ethanol has the recognized effect of reversing the compromised bond strength to the whitened surface (Sung et al., 1999). These methodological differences may justify the disagreement with our results.

The $\mu$ SBS values obtained in this study correlate with the results of the failure analysis. In the 38HP-AT and $38 \mathrm{HP}$ groups, adhesive failures were the most frequent. This failure mode, which occurred entirely at the adhesive interface, demonstrates the compromise potential of residual peroxides from bleaching on the adhesive restorative procedures (Cavalli et al., 2018). Furthermore, these results corroborate the non-efficacy of the AT use with respect to hybrid layer formation and bond strength (Thapa et al.; Harrison et al.). The failure mode, predominantly mixed, associated with SA use indicated the benefits of this antioxidant in the adhesive interface compared to the bleached surface with or without the use of AT. These (mixed) failures are attributed to thermo-mechanical ablation that can compromise the physical characteristics of the dentin substrate and the restorative material (Jacker-Guhr et al., 2019). Not surprisingly, in the NB group, the cohesive failure mode was predominant. This finding suggests the improvement of adhesive procedures, when performed without competing with the residual products of bleaching (Kum et al., 2004).

Our study demonstrated that there are no beneficial effects of using $10 \%$ AT gel for 10 min in reversing the negative effects of tooth whitening on adhesive 
restorative procedures of endodontically treated teeth These findings point out that at the moment, in this concentration, application period, and form of presentation, AT is still clinically unviable. More efforts are needed to completely clarify its mechanism and explore its possible correct indication in the adhesive procedures immediately after bleaching.

\section{CONCLUSION}

Use of $10 \%$ AT gel had no immediate beneficial effect in the hybrid layer formation and micro-shear bond strength. SA promotes a beneficial effect in hybrid layer formation, which was not reflected on the $\mu$ SBS. The findings of this study do not suggest any change in the recommended delay time for definitive restorations of the bleached tooth structure.

\section{ACKNOWLEDGMENTS}

The authors would like to thank Prof. Regina Guenka Palma-Dibb, Department of Restorative Dentistry, School of Dentistry of Ribeirão Preto, University of São Paulo, Brazil for supporting in the microscopy analysis.

SILVA, A. M.; JORDÃO-BASSO, K. C. F.; ALENCAR, C. M.; ZANIBONI, J. F.; ALVES DE CAMPOS, E. \& KUGA, M. C. Efecto del ascorbato de sodio o alfa-tocoferol sobre la interfaz resina-dentina y la fuerza de unión después del tratamiento de endodoncia y blanqueamiento. Int. J. Odontostomat., 15(3):586-594, 2021.

RESUMEN: El objetivo de este estudio in vitro fue evaluar los efectos de dos antioxidantes (ascorbato de sodio [AS] y alfa-tocoferol [AT]) sobre la interfaz adhesiva y la fuerza de unión de la dentina inmediatamente después del blanqueamiento con peróxido de hidrógeno al 38 \% (38HP) en endodoncia. -Dientes tratados. Se llevaron a cabo dos etapas de experimentación. Los incisivos bovinos se dividieron en cuatro grupos ( $n=10$ / grupo para cada experimento): NB, coronas restauradas no blanqueadas; 38HP, coronas blanqueadas y restauradas inmediatamente; $38 \mathrm{HP}$ AS, coronas blanqueadas y uso SA; y 38HP-AT, coronas blanqueadas y uso de AT. La longitud de la capa híbrida en dentina $(\mu \mathrm{m})$ y la fuerza de unión (MPa) se evaluaron con láser de microscopía confocal y la prueba de fuerza de unión por micro-cizallamiento ( $\mu \mathrm{SBS}$ ), respectivamente. El modo de falla se determinó mediante estereomicroscopio. El análisis de los datos se realizó con análisis de varianza (ANOVA) y pruebas de Kruskal-Wallis, Dunn, Tukey y Fisher $(\alpha=0,05)$. De manera similar, se observaron valores más altos de longitud de capa híbrida en los grupos NB y 38HP-AS. Los valores medios más altos de $\mu$ SBS se observaron en el grupo NB $(18,51 \pm 1,33)$, mientras que los valores de SBS para 38HP-AT $(1,68 \pm 0,32)$ fueron similares a los del grupo $38 \mathrm{HP}(1,61 \pm 0,51)(p>0,05)$ y significativamente más bajos que el grupo $38 \mathrm{HP}$-AS $(5,78 \pm 0,71)$. Las fallas adhesivas fueron predominantes en los grupos de $38 \mathrm{HP}$ y $38 \mathrm{HP}-\mathrm{AT}$. Las fallas cohesivas y mixtas se observaron principalmente en los grupos NB y 38HP-AS, respectivamente. En conclusión, la AT no tiene un efecto inmediato sobre la formación de la capa híbrida y el $\mu$ SBS de dentina. Aunque AS promueve un aumento en la formación de capas híbridas, no se refleja en los valores de $\mu$ SBS.

PALABRAS CLAVE: blanqueo, alfa-tocoferol, ascorbato de sodio, fuerza de unión, capa híbrida.

\section{REFERENCES}

Abraham, S.; Ghonmode, W. N.; Saujanya, K. P.; Jaju, N.; Tambe, V. H. \& Yawalikar, P. P.Effect of grape seed extracts on bond strength of bleached enamel using fifth and seventh generation bonding agents. J. Int. Oral Health, 5(6):101-7, 2013.

Briso, A. L.; Rahal, V.; Sundfeld, R. H.; dos Santos, P. H. \& Alexandre, R. S. Effect of sodium ascorbate on dentin bonding after two bleaching techniques. Oper. Dent., 39(2):195-203, 2014.

Briso, A. L.; Toseto, R. M.; Rahal, V.; dos Santos, P. H. \& Ambrosano, G. M. Effect of sodium ascorbate on tag formation in bleached enamel. J. Adhes. Dent., 14(1):19-23, 2012.

Burton, G. W. \& Ingold, K. U. Vitamin $\mathrm{E}$ as an in vitro and in vivo antioxidant. Ann. N. Y. Acad. Sci., 570:7-22, 1989.

Carey, C. M. Tooth whitening: what we now know. J. Evid. Based Dent. Pract., 14:70-6, 2014.

Carvalho, M. A.; Lazari, P. C.; Gresnigt, M.; Del Bel Cury, A. A. \& Magne, P. Current options concerning the endodonticallytreated teeth restoration with the adhesive approach. Braz. Oral Res., 32(Suppl. 1):e74, 2018.

Cavalli, V.; Reis, A. F.; Giannini, M. \& Ambrosano, G. M. The effect of elapsed time following bleaching on enamel bond strength of resin composite. Oper. Dent., 26(6):597-602, 2001.

Cavalli, V.; Sebold, M.; Shinohara, M. S.; Pereira, P. N. R. \& Giannini, M. Dentin bond strength and nanoleakage of the adhesive interface after intracoronal bleaching. Microsc. Res. Tech., 81(4):428-36, 2018.

Comlekoglu, M. E.; Gokce, B.; Kaya, A. D.; Turkun, M. \& Ozpinar, B.Reversal of reduced bond strength after bleaching. Gen. Dent., 58(3):258-63, 2010.

Cross, C. E.; Halliwell, B.; Borish, E. T.; Pryor, W. A.; Ames, B. N.; Saul, R. L. et al. Oxygen radicals and human disease. Ann. Intern. Med., 107(4):526-45, 1987.

Cvitko, E.; Denehy, G. E.; Swift, E. J.\& Pires, J. A. Bond strength of composite resin to enamel bleached with carbamide peroxide. J. Esthet. Dent., 3(3):100-2, 1991.

Doumani, M.; Alotaibi, A. N.; Hussain, F. A.; Alsweed, A. A.; Mandorah, A. O.; Qaddoura, K. A. \& Alanazi, S. M. Internal bleaching of endodontically treated teeth: a dental practitioner's perspective from Kingdom of Saudi Arabia. J. Contemp. Dent. Pract., 20(10):1141-5, 2019. 
Elawsya, M. E.; El-Shehawy, T. M. \& Zaghloul, N. M. Influence of various antioxidants on micro-shear bond strength of resin composite to bleached enamel. J. Esthet. Restor. Dent., 33(2):371-9, 2021.

Freire, A.; Souza, E. M.; de Menezes Caldas, D. B.; Rosa, E. A.; Bordin, C. F.; de Carvalho, R. M. \& Vieira, S. Reaction kinetics of sodium ascorbate and dental bleaching gel. J. Dent., 37(12):9326, 2009.

Garcia, E. J.; Oldoni, T. L.; Alencar, S. M.; Reis, A.; Loguercio, A. D. \& Grande, R. H. Antioxidant activity by DPPH assay of potential solutions to be applied on bleached teeth. Braz. Dent. J., 23(1):227, 2012.

Guarda, M. B.; Di Nizo, P. T.; Abuna, G. F.; Catelan, A.; Sinhoreti, M. A. C. \& Vitti, R. P. Effect of Electric Current-assisted Application of Adhesives on their Bond Strength and Quality. J. Adhes. Dent., 22(4):393-8, 2020.

Harrison, M. S.; Wang, Y.; Frick, K. J.; Moniz, J. \& Walker, M. P. Effects of alpha-tocopherol antioxidant on dentin-composite microtensile bond strength after sodium perborate bleaching. $J$. Endod., 45(8):1053-9, 2019.

Imani, M. M.; Azizi, F.; Bahrami, K.; Golshah, A. \& Safari-Faramani, R. In vitro bleaching effect of hydrogen peroxide with different time of exposition and concentration on shear bond strength of orthodontic brackets to human enamel: A meta-analysis of in vitro studies. Int. Orthod., 18(1):22-31, 2020.

Jacker-Guhr, S.; Sander, J. \& Luehrs, A. K. How "universal" is adhesion? Shear bond strength of multi-mode adhesives to enamel and dentin. J. Adhes. Dent., 21(1):87-95, 2019.

Kavitha, M.; Selvaraj, S.; Khetarpal, A.; Raj, A.; Pasupathy, S. \& Shekar, S. Comparative evaluation of superoxide dismutase, alpha-tocopherol, and $10 \%$ sodium ascorbate on reversal of shear bond strength of bleached enamel: An in vitro study. Eur. J. Dent., 10(1):109-15, 2016.

Kuga, M. C.; dos Santos Nunes Reis, J. M.; Fabrício, S.; BonettiFilho, I.; de Campos, E. A. \& Faria, G. Fracture strength of incisor crowns after intracoronal bleaching with sodium percarbonate. Dent. Traumatol., 28(3):238-42, 2012.

Kum, K. Y.; Lim, K. R.; Lee, C. Y.; Park, K. H.; Safavi, K. E.; Fouad, A. F. \& Spångberg, L. S. Effects of removing residual peroxide and other oxygen radicals on the shear bond strength and failure modes at resin-tooth interface after tooth bleaching. Am. J. Dent., 17(4):267-70, 2004

Lai, S. C.; Mak, Y. F.; Cheung, G. S.; Osorio, R.; Toledano, M.; Carvalho, R. M.; Tay, F. R. \& Pashley, D. H. Reversal of compromised bonding to oxidized etched dentin. J. Dent. Res., 80(10):1919-24, 2001.

Morgan, L. F. \& Montgomery, S. An evaluation of the crown-down pressureless technique. J. Endod., 10(10):491-8, 1984.

Muraguchi, K.; Shigenobu, S.; Suzuki, S. \& Tanaka, T. Improvement of bonding to bleached bovine tooth surfaces by ascorbic acid treatment. Dent. Mater. J., 26(6):875-81, 2007.

Nari-Ratih, D. \& Widyastuti, A. Effect of antioxidants on the shear bond strength of composite resin to enamel following extracoronal bleaching. J. Clin. Exp. Dent., 11(2):e126-32, 2019.

Nascimento, G. C. R.; Ribeiro, M. E. S.; Guerreiro, M. Y. R.; de Souza Cruz, E. L.; Pinheiro, J. J. V. \& Loretto, S. C. Effect of sodium ascorbate on bond strength and metalloproteinases activity in bleached dentin. Clin. Cosmet. Investig. Dent., 11:25965,2019

Perdigão, J. Dentin bonding-variables related to the clinical situation and the substrate treatment. Dent. Mater., 26(2):e24-37, 2010.

Rezaei, M.; Aliasghar, E.; Rezvani, M. B.; Chiniforush, N. \& Moradi, Z. Effect of Er: YAG laser on microtensile bond strength of bleached dentin to composite. J. Lasers Med. Sci., 10(2):11724, 2019.

Sasaki, R. T.; Flório, F. M. \& Basting, R. T. Effect of $10 \%$ sodium ascorbate and $10 \%$ alpha-tocopherol in different formulations on the shear bond strength of enamel and dentin submitted to a home-use bleaching treatment. Oper. Dent., 34(6):746-52, 2009.

Shimada, Y.; Iwamoto, N.; Kawashima, M.; Burrow, M. F. \& Tagami, $\mathrm{J}$. Shear bond strength of current adhesive systems to enamel, dentin and dentin-enamel junction region. Oper. Dent., 28(5):58590, 2003.

Souza-Gabriel, A. E.; Vitussi, L. O.; Milani, C.; Alfredo, E.; Messias, D. C. \& Silva-Sousa, Y. T. Effect of bleaching protocols with 38 $\%$ hydrogen peroxide and post-bleaching times on dentin bond strength. Braz. Dent. J., 22(4):317-21, 2011.

Sung, E. C.; Chan, S. M.; Mito, R. \& Caputo, A. A. Effect of carbamide peroxide bleaching on the shear bond strength of composite to dental bonding agent enhanced enamel. J. Prosthet. Dent., 82(5):595-9, 1999.

Thapa, A.; Vivekananda, P. A. \& Thomas, M. S. Evaluation and comparison of bond strength to $10 \%$ carbamide peroxide bleached enamel following the application of $10 \%$ and $25 \%$ sodium ascorbate and alpha-tocopherol solutions: An in vitro study. J. Conserv. Dent., 16(2):111-5, 2013.

Titley, K. C.; Torneck, C. D.; Smith, D. C.; Chernecky, R. \& Adibfar, A. Scanning electron microscopy observations on the penetration and structure of resin tags in bleached and unbleached bovine enamel. J. Endod., 17(2):72-5, 1991.

Unlu, N.; Cobankara, F. K. \& Ozer, F. Effect of elapsed time following bleaching on the shear bond strength of composite resin to enamel. J. Biomed. Mater. Res. B Appl. Biomater., 84(2):363-8, 2008.

Whang, H. J. \& Shin, D. H. Effects of applying antioxidants on bond strength of bleached bovine dentin. Restor. Dent. Endod., 40(1):37-43, 2015.

Zhang, H.; Shao, S.; Du, A.; Wang, Y.; Cheng, B. \& Zhang, Z. Comparative evaluation of two antioxidants on reversing the immediate bond strength of bleached enamel: in vitro study. Med. Sci. Monit., 26:e920481, 2020.

Corresponding author:

Aryvelto Miranda Silva

Department of Restorative Dentistry

Araraquara Dental School

São Paulo State University (UNESP)

RuaHumaitá, 1680 - Centro.Araraquara

São Paulo, ZIP Code: 14.801-903

BRAZIL

E-mail: aryveltomirand@gmail.com 